\title{
Port Pirie Cohort Study: Childhood blood lead and neuropsychological development at age two years
}

\author{
N R WIGG, ${ }^{1}$ G VVIMPANI,${ }^{2}$ A J MCMICHAEL, ${ }^{3}$ PA BAGHURST, ${ }^{4}$ E F ROBERTSON, ${ }^{5}$ \\ AND R J ROBERTS ${ }^{1}$ \\ From the Child Adolescent and Family Health Service, South Australia,' the Department of Paediatrics, Flinders \\ Medical Centre, ${ }^{2}$ the Department of Community Medicine, University of Adelaide, ${ }^{3}$ the Division of Human \\ Nutrition, Commonwealth Scientific and Industrial Research Organisation (Australia); 4 and the Department of \\ Chemical Pathology, Adelaide Children's Hospital. ${ }^{5}$
}

SUMmaRY The Port Pirie Cohort Study is an ongoing prospective study of the relationship between exposure to environmental lead within a lead smelter community, and neuropsychological development in early childhood. Over 600 children, originally recruited during antenatal life, underwent serial blood lead estimations up to two years of age. Systematic interview information was collected on a range of variables, and formal developmental assessment (Bayley Scales of Infant Development) was carried out at 24 months of age.

Blood lead concentrations measured antenatally (maternal), at delivery (maternal and umbilical cord) and postnatally at 6,15 and 24 months were negatively correlated $(\mathrm{p}<0.05)$ with mental development at 24 months of age. Geometric mean blood lead concentrations $(\mu \mathrm{g} / \mathrm{dl})$ were 14.3, 20.8 and 21.2 at 6,15 and 24 months of age respectively.

When multiple covariates, including maternal IQ, were controlled for in multiple regression analysis, a statistically significant $(\mathrm{p}<0.01)$ inverse association was observed between blood lead concentration $(\mathrm{PbB})$ measured at 6 months of age and mental development at 2 years of age. No such association was evident for psychomotor development. When the quality of the home environment (HOME Score) was added to the multiple regression model, the inverse association between blood lead concentration at 6 months of age and mental development at 2 years persisted, albeit less strongly $(p=0.07)$. From this anaylsis, it is estimated that a child with $\mathrm{PbB}$ of $30 \mu \mathrm{g} / \mathrm{dl}$ at age 6 months will have a deficit of 3.3 points (approximately $3 \%$ ) on the Bayley Mental Development Scale relative to a child with $\mathrm{PbB}$ of $10 \mu \mathrm{g} / \mathrm{dl}$.

The neuropsychological sequelae of acute lead encephalopathy are well documented. Uncertainty persists about the nature of adverse effects of lesser levels of lead exposure upon the neuropsychological development of young children. ${ }^{12}$ A recent review has noted a progressive decline over the past 20 years in the lowest blood lead concentration (PbB) considered dangerous enough to warrant medical attention. ${ }^{3}$

In 1984, the UK Medical Research Council concluded from a literature review that "a moderate elevation of body lead burden as found in some British children has little or no effect on IQ". 4 That review depended primarily on studies that were crosssectional, relied on tooth-lead to estimate prior lead exposure, or were confined to children of schoolage. ${ }^{14-6}$ More recently, a large cross-sectional study of children aged 6-9 years in Edinburgh reported an inverse relationship between blood lead concentration and measures of cognitive ability and educational attainment. $^{7}$

Few data exist about the effects of environmental lead exposure on the neuropsychological development of children under school age. Recently, results have been reported from two prospective studies. Among 249 children in Boston, USA, umbilical cord $\mathrm{PbB}$ was inversely related, after multiple confounder adjustment, to cognitive development measured at 6-monthly ages up to two years. ${ }^{8}$ However, no such relationship existed with postnatal $\mathrm{PbB}$ measures. A study in Cincinnati reported an inverse association between fetal and post-natal lead exposure and motor development in infancy. ${ }^{9}$

When the primary source of lead is exposure to lead-containing dirt/dust, childhood $\mathrm{PbB}$ peaks at 
around two years of age. ${ }^{1011}$ This suggests that maximum exposure to environmental lead occurs during the second year of life, thus overlapping with the period of rapid growth and development of the immature central nervous system. Hence studies of school-age children cannot examine the child's neuropsychological performance at an age when the developing nervous system may be most vulnerable to environmental influences.

During 1979-82, pregnant women were recruited for a prospective study of lead exposure in relation to pregnancy outcome and early childhood development. The women lived in the South Australian industrial city of Port Pirie (population 16000) and the surrounding agricultural districts. Because of the longstanding operation of Australia's largest lead smelter on the immediate periphery, and upwind, of the city, the Port Pirie community has been exposed throughout this century to substantial accumulation of lead and other heavy metals in topsoil and dust.

The primary aim of this ongoing cohort study is to examine early childhood development, up to the age of 7 years, in relation to cumulative lead exposure, as assessed by lead concentrations in maternal blood, placenta, children's blood, and deciduous teeth. This paper decribes the relationship between $\mathrm{PbB}$, measured antenatally and postnatally, and child development as assessed at age two years.

\section{Methods}

The original cohort of 723 neonates represented approximately $90 \%$ of all children born in the city of Port Pirie or in the surrounding agricultural area, which includes four smaller towns, between September 1979 and October $1982 .{ }^{12}$

Venous blood samples were taken from the pregnant women on enrolment into the study (14-20 weeks gestation), early in the third trimester, and at delivery. Umbilical cord blood samples were collected at birth. At postnatal ages of 6,15 and 24 months, and annually thereafter, capillary bloods samples were collected into heparin under standardised conditions ${ }^{13}$ by a trained nurse-interviewer who followed the capillary collection technique meticulously.

The validity of the capillary blood sampling was separately assessed on a sample of 47 metropolitan Adelaide children aged $2-4$ years. ${ }^{14} \mathrm{~A}$ very close correlation $(r=0.97)$ was observed between $\mathrm{PbB}$ values obtained by a capillary sampling technique (identical with that used in the Port Pirie study) and those obtained by simultaneous venous sampling. $\mathrm{PbB}$ was estimated by atomic absorption spectrometry with electrothermal atomisation after standard complexing and extraction of lead. ${ }^{15} \mathrm{PbB}$ values were standardised to a packed cell volume of $35 \%$ for pregnant women, $50 \%$ in cord blood, and $35 \%$ in infants.

At ages 6, 15 and 24 months, the numbers of children remaining in the cohort were 652,619 and 601 , respectively. Children were lost to follow-up primarily because of families leaving the Port Pirie district. For a smaller number of children, their families elected to discontinue their participation in the study. Three children were excluded from followup because of chronic neurological disorders not related to lead exposure.

At 24 months of age $(+/-2$ weeks) the developmental status of each child was measured with the Bayley Scales of Infant Development. ${ }^{16}$ This instrument comprises a Mental Scale of 163 items and a Motor Scale of 81 items. The Mental Scale assesses sensory-perceptual acuities and discriminations, and ability to respond to these; it also assesses acquisition of "object constancy", memory, learning, problemsolving ability, early language and speech development, and ability to form generalisations and classifications. Results are expressed as a single standard score-the Mental Development Index (MDI). The Motor Scale measures gross and fine motor coordination. In assessing motor skills and coordination it is not concerned with functions that are primarily "mental" or "intelligent" in nature. Results are expressed as a single standard score-the Psychomotor Development Index (PDI).

From the original standardisation carried out in a large representative sample of children in the USA, aged 2-30 months, the expected mean score for each scale is 100 (standard deviation $=16$ ). Both scales have good tester-observer reliability and test-retest reliability, and the MDI has good correlation $(r=0.57)$ with the Stanford Binet Intelligence Scale over the age-range common to the two tests (24-30 months). ${ }^{16}$

A single research psychologist conducted all of the Bayley Scales testing. The psychologist was "blind" to the child's previous or current blood lead estimations. Developmental testing was conducted in a clinic setting on a different day from blood collection.

At the time of each blood collection, the nurseinterviewer obtained, by structured interview, information on a wide range of demographic, psychosocial, medical, behavioural and developmental variables. Data were collected on these variables because of their possible confounding (and interactive) effects upon any association between body lead burden and neuropsychological development.

When children were aged 3-4 years, maternal IQ was assessed with the Weschler Adult Intelligence Scale-Revised (WAIS-R). ${ }^{17}$ Maternal IQ scores were not obtained for 163 of the mothers, predominantly because of refusal to be tested; their 
children were assigned to a separate IQ category so that the remaining covariate information could still be incorporated in the multivariable analysis.

The HOME Inventory was also applied in all cases. This is an observation/interview technique that assesses the quality of stimulation available to the child in the home. ${ }^{18}$ It provides a more sensitive and direct measure than do structural and status indices such as parental occupation, education, family size, and type of dwelling. It measures processes that mediate the child's development, such as parent-child transactions, the types of play objects available, specific events and stimulating experiences that occur in the home environment, and the general quality of the physical home environment. The instrument comprises six sub-scales (emotional and verbal responsiveness of parent; parental acceptance of child; maternal involvement with child; organisation of home environment; provision of appropriate play materials; variety in daily stimulation), and those aspects of the home environment measured by this instrument have demonstrated a strong relationship with intellectual and language development in early childhood. ${ }^{18} 19$ It has been shown to have good reliability. Its use in such studies was recommended by the First International Lead Workshop (held in Cincinnati in 1981). ${ }^{20}$ The instrument was administered during a visit to the child's home at age 3 years by a nurse trained in its use by a psychologist.

\section{STATISTICAL ANALYSES}

Since blood lead concentrations are log-normally distributed, geometric rather than arithmetric means are presented here. The standard error factor in the tables must therefore be interpreted as a multiplier. Log $\mathrm{PbB}$ was used in the calculations of correlations between $\mathrm{PbB}$ and Bayley scores. An "integrated PbB" has been calculated by trapezoidal integration of each individual's blood lead curve derived from serial $\mathrm{PbB}$ estimates from umbilical cord blood, and the 6,15 and 24 month blood samples, and is presented as a summary estimate of total lead exposure in post-natal life.

\section{Results}

Variations in mean $\mathrm{PbB}$ by age are shown in table 1. The mean $\mathrm{PbB}$ rises sharply between the ages of 6 and 15 months. The maximum value occurred at 2 years of age $(21 \cdot 2 \mu \mathrm{g} / \mathrm{dl})$, after which a slight but steady decline has occurred in this cohort at 3 and 4 years. There were no significant differences in $\mathrm{PbB}$ between females and males. The range of individual blood lead concentrations observed within this initial 2-year age span was $2-67 \mu \mathrm{g} / \mathrm{dl}$.
Table 1 Geometric mean blood lead concentration by age

\begin{tabular}{|c|c|c|c|}
\hline Age & $\begin{array}{l}\text { No of } \\
\text { children }\end{array}$ & $\begin{array}{l}\text { Mean blood } \\
\text { lead ( } \mu g / d l)\end{array}$ & $\begin{array}{l}95 \% \text { Confidence } \\
\text { limits }\end{array}$ \\
\hline $\begin{array}{l}\text { Umbilical Cord } \\
6 \text { months } \\
15 \text { months } \\
2 \text { years } \\
\text { Integrated postnatal }\end{array}$ & $\begin{array}{l}523 \\
579 \\
583 \\
590 \\
497\end{array}$ & $\begin{array}{r}8 \cdot 3 \\
14 \cdot 4 \\
20 \cdot 9 \\
21 \cdot 2 \\
18 \cdot 1\end{array}$ & $\begin{array}{r}8 \cdot 0-8 \cdot 6 \\
13 \cdot 9-14 \cdot 8 \\
20 \cdot 2-21 \cdot 5 \\
20 \cdot 6-21 \cdot 8 \\
16 \cdot 5-19 \cdot 6\end{array}$ \\
\hline
\end{tabular}

The Bayley Scales of Infant Development were completed for 595 children at 24 months of age. The mean Bayley Mental Development Index (MDI) was $109 \cdot 2(\mathrm{SD}=15 \cdot 3)$; and the mean Bayley Psychomotor Development Index (PDI) was 105.3 (SD=14.8). There was no statistically significant difference in mean Index scores between the Port Pirie $(n=450)$ and non-Port Pirie $(n=145)$ children.

Table 2 Correlations between blood lead concentrations at serial ages and Bayley developmental indices at 24 months

\begin{tabular}{lllll}
\hline & \multicolumn{2}{c}{ Pearson correlation coefficient } \\
\cline { 2 - 5 } Blood sample & $\begin{array}{l}\text { Mental } \\
\text { devt. index }\end{array}$ & $\begin{array}{l}\text { Psychomotor } \\
\text { devt. index }\end{array}$ & $\begin{array}{l}\text { No of } \\
\text { children }\end{array}$ \\
\hline Maternal: $14-20$ weeks gestation & -0.06 & -0.05 & 509 \\
& After 20 weeks gestation & $-0.08^{*}$ & -0.02 & 560 \\
& Average prepartum & $-0.11^{*}$ & -0.06 & 586 \\
Child: & At delivery & -0.03 & -0.02 & 524 \\
& Umbilical cord & -0.04 & -0.04 & 520 \\
& 6 months & $-0.12^{*}$ & -0.07 & 575 \\
& 15 months & $-0.12^{*}$ & -0.02 & 579 \\
& 24 months & $-0.18 \dagger$ & -0.02 & 586 \\
& Integrated postnatal & $-0.15 \dagger$ & -0.01 & 494 \\
\hline
\end{tabular}

$<0.05+<0.01$

The Bayley Mental Development Index (MDI) was negatively correlated with $\mathrm{PbB}$ at all ages (table 2 ). The correlation attained statistical significance in both the antenatal and the postnatal periods, but not at time of birth (maternal and umbilical cord blood samples). Conversely, the correlations of the Bayley Psychomotor Index (PDI) with each $\mathrm{PbB}$ were weak, and none achieved statistical significance.

The relationship between PbB and Bayley MDI scores at 24 months was explored further by comparing groups of children who had had "raised" and "never-raised" PbB levels. Children were categorised as "raised" if their PbB had exceeded $30 \mu \mathrm{g} / \mathrm{dl}$ at least once at 6,15 or 24 months of age. The children with raised $\mathrm{PbB}(\mathrm{n}=162)$ had a mean Bayley MDI of $105 \cdot 5$, compared with a mean MDI of 110.9 for children $(n=402)$ whose $\mathrm{PbB}$ was never raised.

A subsequent analysis, based on cumulative postnatal lead exposure, showed that when children were classified into three cumulative exposure groups, a strong inverse association between $\mathrm{PbB}$ history and MDI was evident (table 3). 
Table 3 Association of Bayley MDI with blood lead history

\begin{tabular}{|c|c|c|c|c|}
\hline $\begin{array}{l}\text { Blood lead } \\
\text { concentration }\end{array}$ & $\begin{array}{l}\text { No of } \\
\text { children }\end{array}$ & $\begin{array}{l}\text { Integrated postnatal } \\
\text { blood lead ( } \mu \mathrm{g} / \mathrm{dl})\end{array}$ & Mean $M D I$ & $S E$ \\
\hline $\begin{array}{l}\text { Persistently high } \\
\text { Intermediate } † \\
\text { Persistently low } \neq\end{array}$ & $\begin{array}{r}51 \\
451 \\
62\end{array}$ & $\begin{array}{l}29 \cdot 9 \\
18 \cdot 4 \\
10 \cdot 0\end{array}$ & $\begin{array}{l}102 \cdot 2 \\
109 \cdot 7 \\
112 \cdot 2\end{array}$ & $\begin{array}{l}1.6 \\
0.6 \\
1.6\end{array}$ \\
\hline
\end{tabular}

The relationship to Bayley MDI score of each of those variables considered to be potential determinants of childhood development was examined by univariate and multiple regression analyses. The relationships between 13 such variables

Table 4 Association of sociodemographic, neonatal and behavioural factors with Bayley MDI

\begin{tabular}{|c|c|c|c|}
\hline Factor & $\begin{array}{l}\text { No of } \\
\text { children }\end{array}$ & Mean MDI & $S E$ \\
\hline \multicolumn{4}{|l|}{$\begin{array}{l}\text { Sociodemographic factors: } \\
\text { Maternal age (years): }\end{array}$} \\
\hline$<21$ & 104 & $105 \cdot 7$ & $1 \cdot 5$ \\
\hline $22-29$ & 377 & $110 \cdot 2$ & 0.8 \\
\hline$\geq \mathbf{3 0}$ & 109 & 109.8 & $1 \cdot 3$ \\
\hline \multicolumn{4}{|l|}{ Father's secondary education (years): } \\
\hline unknown & 74 & $99 \cdot 1$ & 1.7 \\
\hline$\leq 3$ & 250 & 108.9 & $1 \cdot 0$ \\
\hline$>3$ & 271 & $112 \cdot 5$ & 0.9 \\
\hline \multicolumn{4}{|l|}{ Mother's secondary education (years): } \\
\hline$\leq 3$ & 286 & $108 \cdot 0$ & 0.8 \\
\hline$>3$ & 289 & $111 \cdot 0$ & 0.9 \\
\hline \multicolumn{4}{|l|}{ Father's workplace: } \\
\hline office & 147 & $111 \cdot 8$ & 1.4 \\
\hline non-office & 438 & $108 \cdot 6$ & 0.7 \\
\hline \multicolumn{4}{|l|}{ Mother's workplace: } \\
\hline away from home & 238 & $111 \cdot 9$ & $1 \cdot 0$ \\
\hline home & 349 & $107 \cdot 6$ & 0.8 \\
\hline \multicolumn{4}{|l|}{ Parental relationship: } \\
\hline living together & 537 & $110 \cdot 2$ & 0.6 \\
\hline living apart & 52 & $100 \cdot 0$ & $2 \cdot 1$ \\
\hline \multicolumn{4}{|l|}{ Mother's antenatal marital status: } \\
\hline single, widowed, divorced & 59 & $102 \cdot 2$ & $2 \cdot 0$ \\
\hline married or defacto & 531 & $110 \cdot 1$ & 0.7 \\
\hline \multicolumn{4}{|l|}{ Child's birth rank: } \\
\hline first born & 274 & 109.9 & $1 \cdot 0$ \\
\hline second born & 199 & $109 \cdot 1$ & $1 \cdot 0$ \\
\hline subsequent & 122 & $108 \cdot 3$ & $1 \cdot 3$ \\
\hline \multicolumn{4}{|l|}{ Neonatal Factors: } \\
\hline \multicolumn{4}{|l|}{ Neonatal oxygen use at birth: } \\
\hline $\begin{array}{l}\text { requred } \\
\text { not required }\end{array}$ & 411 & $\begin{array}{l}100 \cdot 7 \\
110 \cdot 5\end{array}$ & 0.8 \\
\hline \multicolumn{4}{|l|}{ Apgar score at 5 minutes: } \\
\hline $\begin{array}{r}\leq 8 \\
9 \text { or } 10\end{array}$ & $\begin{array}{l}132 \\
448\end{array}$ & $\begin{array}{l}105 \cdot 2 \\
110 \cdot 4\end{array}$ & $\begin{array}{l}1.3 \\
0.7\end{array}$ \\
\hline \multicolumn{4}{|l|}{ Neonatal jaundice: } \\
\hline present & 220 & $108 \cdot 7$ & $1 \cdot 1$ \\
\hline absent & 366 & $109 \cdot 7$ & 0.8 \\
\hline \multicolumn{4}{|l|}{ Size for gestational age: } \\
\hline small & 33 & $101 \cdot 2$ & 2.9 \\
\hline appropriate & 489 & 109.6 & 0.7 \\
\hline large & 56 & $111 \cdot 6$ & $2 \cdot 0$ \\
\hline \\
\hline $\begin{array}{l}\text { Mouthing activity at } 15 \text { months: } \\
\text { frequent }\end{array}$ & & 107.9 & 0.9 \\
\hline intermediate & 306 & 110.0 & 0.9 \\
\hline never & 42 & 113.7 & $2 \cdot 8$ \\
\hline
\end{tabular}

and MDI scores, as determined by stratified univariate analysis, are shown in table 4. Other variables which were examined but are not reported here were either highly correlated with variables reported, or provided no explanatory power in the analyses.

Parental education, parental workplace, and parental relationship were associated with Bayley MDI. The lowest mean Bayley MDI scores were for children of separated parents and for mothers with "single-parent" status in the antenatal period. (These two categories overlapped substantially with another category-"father's education unknown", a circumstance also associated with a low MDI score). Of the neonatal factors, oxygen requirement at birth, a neonatal Apgar rating of 8 or less at five minutes, and low birth weight for gestational age were each associated inversely with Bayley MDI score at 24 months.

At interview, parents were asked about their child's mouthing activity (placing objects in mouth, sucking fingers) whilst playing outside. An increased reported frequency of mouthing behaviour at 15 months of age was associated with a decrease in Bayley MDI score at 24 months (table 4).

Maternal intelligence is a well-established correlate of childhood development. A strong positive association is evident in table 5 .

Table 5 Bayley MDI by maternal intelligence score (WAIS)

\begin{tabular}{lcll}
\hline Maternal WAIS & $\begin{array}{l}\text { No of } \\
\text { subjects }\end{array}$ & Bayley MDI & $S E$ \\
\hline$\leq 80$ & 50 & $98 \cdot 3$ & $2 \cdot 7$ \\
$81-90$ & 117 & $108 \cdot 7$ & $1 \cdot 4$ \\
$91-100$ & 145 & $111 \cdot 1$ & $1 \cdot 3$ \\
$>100$ & 94 & 114.0 & 1.6 \\
Refused or unavailable & 163 & $108 \cdot 1$ & $1 \cdot 0$ \\
All mothers & 592 & $109 \cdot 3$ & 0.6 \\
\hline
\end{tabular}

A multiple regression analysis was undertaken with and without maternal IQ entered into the multivariable model. The linear model was not significantly improved by the addition of quadratic terms in continuous covariates. $\mathrm{PbB}$ was entered after the above-mentioned 13 other sociodemographic, neonatal and behavioural variables had been entered.

With maternal IQ absent from the model there was a statistically significant negative association $(p<0.05)$ between $\mathrm{PbB}$, measured either at 6 months of age or as the integrated postnatal average, and Bayley MDI score at 24 months (table 6). When maternal IQ was introduced into the model the statistically significant association persisted for $\mathrm{PbB}$ at 6 months of age and for the integrated postnatal $\mathrm{PbB}$. 
Table 6 Partial linear regression coefficients for each blood lead measure with and without maternal IQ and HOME score in the model*

\begin{tabular}{llll}
\hline & \multicolumn{2}{l}{$\begin{array}{l}\text { Regression coefficients } \\
\text { (change in MDI per unit change in blood lead }[\mu g / d l])\end{array}$} \\
\cline { 2 - 4 } & & & $\begin{array}{l}\text { Controlling for } \\
\text { maternal IQ and }\end{array}$ \\
Blood lead measure & $\begin{array}{l}\text { Ignoring } \\
\text { maternal IS }\end{array}$ & $\begin{array}{l}\text { Controlling for } \\
\text { maternal IQ }\end{array}$ & HOME score \\
\hline Average antenatal & -0.26 & -0.21 & -0.07 \\
Delivery & +0.19 & +0.27 & +0.23 \\
Cord & +0.05 & +0.07 & +0.10 \\
6 months & $-0.24(\mathrm{p}=0.01) \dagger$ & $-0.24(\mathrm{p}=0.01)$ & $-0.16(\mathrm{p}=0.07)$ \\
15 months & -0.09 & -0.06 & -0.03 \\
24 months & -0.16 & -0.12 & -0.05 \\
Integrated postnatal & $-0.26(\mathrm{p}=0.03)$ & $-0.22(\mathrm{p}=0.05)$ & $-0.12(\mathrm{p}=0.19)$ \\
& & &
\end{tabular}

*The model contains the 13 socioeconomic, demographic, neonatal and behavioural factors shown in table 4.

tOne-tailed significance values

The relationships of $\mathrm{PbB}$ and a range of possible covariates to psychomotor development (Bayley PDI) were also examined. No statistically significant association was found.

In univariate analysis, there was a strong positive correlation between the HOME score and Bayley MDI. A very low HOME score also appeared to be associated with a low Bayley PDI, but there was otherwise no clear relationship between these two variables. Since the HOME score was negatively correlated with integrated postnatal $\mathrm{PbB}$, thus making it a potential confounder, a multiple regression analysis was undertaken in which $\mathrm{PbB}$ measures were entered after both HOME scores and maternal IQ had been entered (table 6). Inclusion of the HOME score in the multivariable model resulted in attenuation of the residual effect of $\mathrm{PbB}$ on Bayley MDI. The relationship between $\mathrm{PbB}$ at 6 months and Bayley MDI remained almost statistically significant $(p=0.07)$, whereas the existence of a real relationship between the integrated postnatal $\mathrm{PbB}$ and Bayley MDI became less probable $(p=0 \cdot 19)$.

The results of this multivariable analysis indicate that, other factors remaining constant, a child's MDI score at 2 years will decrease by 1.6 points (i.e. $1.5 \%$ ) for every $10 \mu \mathrm{g} / \mathrm{dl}$ rise in $\mathrm{PbB}$ at six months of age. Thus, it would be predicted that a child with a $\mathrm{PbB}$ of $30 \mu \mathrm{g} / \mathrm{dl}$ at age six months would have a $3 \cdot 2 \%$ deficit in mental developmental attainment at age two years relative to a child with a $\mathrm{PbB}$ of $10 \mu \mathrm{g} / \mathrm{dl}$.

\section{Discussion}

The developing central nervous system of the young human becomes less sensitive to subtle environmental influences with increasing age. ${ }^{20}$ It is therefore important to assess the neuropsychological effects of environmental lead exposure in very young children when the impact of the exposure on the developing central nervous system is likely to be maximal.

The findings reported here indicate that elevations in $\mathrm{PbB}$ at six months of age have greater negative effect upon infant mental development than do elevations at other times in the antenatal period and the first two years of life. At six months of age few infants are independently mobile, and elevations in $\mathrm{PbB}$ may thus reflect sustained exposure to a lead-contaminated home environment. In contrast, children with elevated $\mathrm{PbB}$ at older ages could have episodic or transient exposure to environmental lead, dependent upon the level of contamination of various environmental loci in combination with the child's mobility and hand-tomouth activity.

Bellinger and colleagues have recently reported, from their Boston cohort, a negative association between antenatal lead exposure (using umbilical cord blood lead concentration as the index) and MDI measures during the first two years of life. ${ }^{7}$ However, in this present study there was no clear association between cord $\mathrm{PbB}$ and infant development at two years. Such differences in the results of studies may reflect differences in the mean and range of $\mathrm{PbB}$ in the population of children being studied, and in the extent of environmental, social, and behavioural heterogeneity within the study population. Ease of detection of any relatively weak effects of lead would be enhanced by selecting an otherwise more homogeneous population of children. Another reason that no effect of umbilical PbB on Bayley MDI at 2 years has been observed in this cohort may be because of the likely greater impact of the much higher levels of $\mathrm{PbB}$ encountered postnatally.

The multiple regression strategy adopted in this study is potentially conservative in that those variables that are associated with a low Bayley MDI (for example, single parent family, father in non-office occupation, low maternal IQ, and low HOME score) may well exert some of their effect upon MDI through an associated increased exposure of the child to environmental lead. Therefore, by according priority in the multivariable model to these variables, with their associated but indeterminate lead-exposure content, the residual "unconfounded" effect of $\mathrm{PbB}$ on mental development may underestimate the true effect-and will also be more difficult to detect.

Consistent with earlier studies of the determinants of child development, parental education, the marital status of parents, and Apgar score each accounted for some of the variance in MDI scores within this study population. Inclusion of those variables, along with the HOME score and maternal IQ in the multiple regression model, attenuated the estimated independent effect of $\mathrm{PbB}$ on Bayley MDI. Nevertheless, and despite the conservative (potentially 
over-controlled) multivariate data analysis, the inverse relationship between $\mathrm{PbB}$ at six months and Bayley MDI at two years retains borderline statistical significance. Further, the estimated partial regression coefficients for all $\mathrm{PbB}$ measures (excluding those measured at birth) remain negative (table 6 , righthand column).

These results indicate that, with other factors remaining constant, a child's MDI at 24 months will be 1.6 points (equivalent to $1.5 \%$ ) lower for every $10 \mu \mathrm{g} / \mathrm{dl}$ rise in $\mathrm{PbB}$ at 6 months of age. Such a decrement may be of little clinical significance to the individual child. However, in population terms, a decrease of several percentage points in the mean score on a test of mental/intellectual ability for a group of children will be associated with an increased proportion of children with functionally significant deficit, compared with the general population of children. ${ }^{2}$ Moreover, in view of the fit of a linear model in multiple regression analysis, these findings provide no evidence of a threshold effect.

Important in the interpretation of these results is the predictive value of tests of infant development for subsequent intellectual and academic performance throughout childhood. There is a high degree of correlation between Bayley MDI score and IQ score measured on the Stanford-Binet Intelligence Scale $(r=0.57) .{ }^{16}$ Preliminary analysis of data obtained at age four years from children in this cohort shows a high correlation $(r=0.58)$ between Bayley MDI and the General Cognitive Index of the McCarthy Scales of children's abilities. ${ }^{22}$ The negative relationship between postnatal $\mathrm{PbB}$ and children's mental ability persists at age four years within this cohort, and, from recently-completed analyses, appears to be stronger at this latter age. Those results will be the subject of a separate report.

We acknowledge the excellent co-operation of families who participated in this study, their doctors, and the staff of local hospitals. The study has depended upon the skills of Barbara Hobson RN, Chris Mavromatis RN, Mary-Anne Lange RN, Bronwen Morgan RN, and Louise Thomson RN.

We also thank the Adelaide Children's Hospital Chemical Pathology Department (Ms B King undertook the lead assays, while $\mathrm{Mr} \mathrm{R}$ Oldfield and Dr A C Pollard provided technical advice), the staff of the CSIRO Division of Human Nutrition who assisted with data analysis (Ms M Padhye, Ms J Rogers, Ms J Syrette), and $\mathrm{Mr} \mathrm{C}$ Greeneklee, Manager of the Commonwealth Health Department Laboratory in Port Pirie.
This study has been supported by a series of grants from the National Health and Medical Research Council, with additional assistance from the South Australian Health Commission.

Reprint requests to: Dr N R Wigg, Child Adolescent and Family Health Service, 295 South Terrace, Adelaide, South Australia 5000.

\section{References}

${ }^{1}$ Smith M, Delves T, Lansdown R, Clayton B, Graham P. The effects of lead exposure on urban children: The Institute of Child Health/Southampton Study. Dev Med Child Neurol 1983; 25, Suppl 47.

2 Needleman HL. Low level lead exposure and neuropsychological performance. In: Rutter M, Russell Jones R, eds. Lead versus health. Chichester: J. Wiley and Sons, 1983.

${ }^{3}$ Davis JM, Svendsgaard DJ. Lead and child development. Nature 1987; 329: 297-300.

${ }^{4}$ Medical Research Council. The neuropsychological effects of lead in children. A review of recent research, 1979-1983. London: Medical Research Council, 1984.

${ }^{5}$ Needleman HL, Gunneo C, Leviton A, et al. Deficits in psychologic and classroom performance of children with elevated dentine lead levels. $N$ Eng J Med 1979; 300: 689-95.

${ }^{6}$ Winneke G, Kramer U, Brockhause A, et al. Neuropsychological studies in children with elevated tooth-lead concentrations. Part II: Extended Study. Int Arch Occup Environ Health 1982; 51: 231-52.

${ }^{7}$ Fulton M, Raab G, Thomson G, Laxen D, Hunter R, Hepburn $W$. The influence of blood lead on the ability and attainment of children in Edinburgh. Lancet 1987; i: $1221-6$.

${ }^{8}$ Bellinger D, Leviton A, Waternaux C, Needleman $H$, Rabinowitz $M$. Longitudinal analyses of prenatal and postnatal lead exposure and early cognitive development. N Eng J Med 1987; 316: 1037-43.

${ }^{9}$ Dietrich KN, Krafft KM, Bier M, Bornschein RL, Berger $O$, Succop PA. The effects of fetal and postnatal lead exposure on neurobehavioural development during the first year of life. Abstract, International Workshop on 'Lead exposure and neurobehavioural effects in children', Edinburgh, 1986.

10 McMichael AJ, Baghurst PA, Robertson EF, Vimpani GV, Wigg NR. The Port Pirie Cohort Study: Blood lead concentrations in early childhood. Med J Aust 1985; 143: 499-503.

${ }^{11}$ National Center for Health Statistics. Blood lead levels for persons age 6 months-74 years: United States, 1976-80. Data from the National Health and Nutrition Examination Survey, Series 11, No. 233 (publication No [PHS] 84-1683). Hyattsville, USA: US Dept of Health and Human Services, 1984.

12 McMichael AJ, Vimpani GV, Roberston EF, Clark PD, Baghurst PA. The Port Pirie Cohort Study: Maternal blood lead and pregnancy outcome. $J$ Epidemiol Community Health 1986; 40: 18-25.

13 Australian Standards Association. Australian Standard 2636. Sampling of venous and capillary blood for the determination of lead content. Canberra, 1983.

14 Lewis MJ, Harrison MC, Calder IC, Esterman AJ, Roder DM, Oldfield RT. Blood lead levels in children in north west Adelaide. Med J Aust 1986; 144: 10, 509-12. 
15 Australian Standards Association. Australian Standard Project No CH/006-0030. Method for the determination of lead in whole blood (Electrothermal Atomization Atomic Absorption spectrophotometric Method). Canberra, 1984.

16 Bayley N. Bayley Scales of Infant Development. New York: The Psychological Corporation, 1969.

17 Wechsler D. Wechsler Adult Intelligence Scale-Revised. New York: The Psychological Corporation, 1981.

18 Bradley R, Caldwell B. Home observation for measurement of the environment. Little Rock, Arkansas: University of Arkansas, 1977.

${ }^{19}$ Bradley R, Caldwell B, Elardo R. Home environment, social status, and mental test performance. $J E d u c$ Psychol 1977; 69: 697-701.

${ }^{20}$ Proceedings of the First International Lead Conference, Cincinnati, Ohio 1981. Department of Environmental Health, University of Cincinnati, 1981.

${ }^{21}$ Dobbing J. The later growth of the brain and its vulnerability. Pediatrics 1974; 53: 2-6.

${ }^{22}$ McCarthy D. Manual for the McCarthy Scales of Children's Abilities. New York: The Psychological Corporation, 1972: 2-12.

Accepted for publication April 1988 